\title{
高減衰積層ゴムの変形履歴積分型復元力モデルに関する研究 A HYSTERESIS MODEL OF HIGH-DAMPING RUBBER BEARINGS USING AN INTEGRAL TYPE DEFORMATION HISTORY CONSTITUTIVE LAW
}

\author{
加藤秀章*, 森 隆 浩**, 室田伸夫***, 石井 建 ${ }^{* * * *}$, 菊地 優***** \\ Hideaki KATO, Takahiro MORI, Nobuo MUROTA, \\ Ken ISHII and Masaru KIKUCHI
}

\begin{abstract}
A new hysteresis model for high-damping rubber bearings is proposed, which has been developed based on an elasto-plastic, integral type deformation history constitutive law. One of the characteristics of the proposed model is the applicability of the same material parameters as the proposed model to finite element method analyses. Firstly, we derive the horizontal biaxial hysteresis model from the elasto-plastic constitutive law. Next, we compare the results of numerical analyses using the proposed hysteresis model with experimental results for tests of high-damping rubber bearings subjected to horizontal biaxial loading, and verify the validity of the proposed model. Lastly, we perform finite element method analyses and numerical analyses using a multi-shear springs model, and the results from each of these cases are compared with results given by the proposed model.
\end{abstract}

Keywords: Seismic isolation, High-damping rubber bearing, Elasto-plastic constitutive law, Hysteresis model, Finite element method 免震, 高減衰積層ゴム, 弾塑性構成則, 復元力モデル, 有限要素法

\section{1.はじめに}

積層ゴムの力学的特性を把握するために、加力時の内部応力・ひ ずみ状態を把握することは重要である。しかし、積層ゴムは、鉛直 方向に数十 MPa の面圧を受け、水平方向には数百\%ものせん断変形 を許容する製品であり、その内部応力・ひずみ状態を実験的に測定 することは難しい。そのため、有限要素法などを用いて解析的に積 層ゴムの内部応力・ひずみ状態を把握する試みが多くなされている 1)6)。積層ゴムの力学的挙動について有限要素法を用いて解析する際 に問題となるのは、積層ゴムの持つ大変形性能に起因する幾何学的 非線形性とゴム材料の持つ材料非線形性をどのような構成則を用い て表現するかである。特に、ゴム材料自体がエネルギー吸収性能を 持つ高減衰積層ゴムは、天然ゴム系積層ゴムのような他の積層ゴム と比較して材料非線形性が強く、せん断変形量と共に指数関数的に 復元力が増加するハードニング現象や最初の載荷過程と比較して 2 度目以降の載荷過程における復元力が低下寸る Mullins 効果などを 伴い複雑な力学特性を示す。このような高減衰積層ゴムの力学特性 を表現するために、その構成則については幾つかの提案がなされて

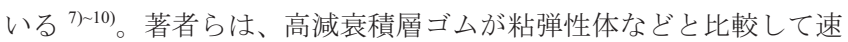
度依存性が小さく弾塑性的な挙動を示すこと、その一方で、クリー プや応力緩和といった粘弾性的挙動を示すことなどの特徴に着目し、 相当ひずみに応じてその応力が緩和する変形履歴積分型の弾塑性構 成則を提案し、高い精度で高減衰積層ゴムの複雑な復元力特性やク
リープ的な挙動を再現できることを確認した ${ }^{11}$ 。

有限要素法は、積層ゴムの内部応力・ひずみ状態を把握することが できる強力なツールであるが、解析モデルの作成や解析に多くの時 間と労力を要する。よって、免震建物の地震時の応答を時刻歴応答 解析などにより求める際には、積層ゴムの形状的な要因を排除し、 その復元力特性のみをばね要素にて表現した復元力モデルが用いら れることが一般的である。高減衰積層ゴムの復元力特性の非線形性 を表現する復元力モデルとしては、修正バイリニアモデル、 Ramberg-Osgood モデル ${ }^{12}$ 、 Kikuchi-Aiken モデル ${ }^{13)}$ などが提案され ている。これらのモデルは水平 1 方向変形時における復元力特性を 表現することを目的としている。しかし、最近、山本ら ${ }^{14)}$ が高減衰 積層ゴムの水平 2 方向変形実験を行った際に、水平 1 方向変形時と 比較してせん断応力が増加する現象が確認されたことから、水平 2 方向変形時の復元力特性を表現しうるモデルの必要性が高まりつつ ある。水平 2 方向変形に対応した復元力モデルについて、既往の研

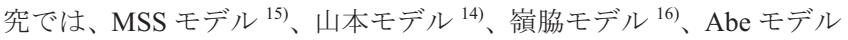
17), 18)などがある。これらのモデルを用いて水平 2 方向変形時の免震 建物の性状についての研究がなされつつある例えば 19)。

上述の通り、有限要素法や復元力モデルは積層ゴムの力学的特性 や免震構造の性状を把握する上で、非常に強力なツールである。し かし、有限要素解析に用いる構成則と復元力モデルの間には、一般 的には力学的支配則に統一性はなく、解析にはそれぞれ独自の材料 
モデルを用意する必要がある。このことは、その解析結果について も独立に扱う必要性があることを示唆するものであり、免震部材の 詳細な力学的性状に関寸る研究と免震建物の力学的性状に関する研 究の間の垣根の 1 つとなっている。

以上の背景から、本研究は積層ゴムの詳細解析に用いられる有限 要素法の構成則を基本式とし、免震建物の時刻歴応答解析に用いる ことができる復元力モデルの提案を目的とする。この復元力モデル は、有限要素法の構成則と力学的支配則が同一なため、同じ材料パ ラメータを用いて解析をすることが可能であり、積層ゴムの形状に よる復元力特性への影響を除くモデル間の差異などを考慮せずに取 り扱うことが可能である。

\section{2. 変形履歴積分型復元カモデル}

\section{1 変形履歴積分型の弾塑性構成則}

本研究では、著者らが考案した変形履歴積分型の弾塑性構成則を 基本式とした。変形履歴積分型の弾塑性構成則とは、Simoの粘弾性 構成則 ${ }^{20}$ における応力の大きな変形速度依存性を取り除いた、変形 速度、即ち時間に依存しない弾塑性構成則である。変形履歴積分型 の弾塑性構成則を(1)式に示す。

$$
\mathbf{S}=2 \frac{\partial \bar{W}_{\infty}}{\partial \mathbf{C}}+2 \sum_{n=1}^{N} g_{n} \int_{0}^{L} \frac{\mathrm{d}}{\mathrm{d} L^{\prime}}\left(\frac{\partial \overline{W_{0}}}{\partial \mathbf{C}}\right) e^{-\left(L-L^{\prime}\right) / l_{n}} \mathrm{~d} L^{\prime}
$$

ここで、 $\mathbf{S}$ は第 2Piola-Kirchhoff 応力を、 $\mathbf{C}$ は右 Cauchy-Green 変形テ ンソルを、 $\bar{W}_{\infty}$ 及び $\bar{W}_{0}$ は材料に固有な等容変形に関するひずみエネ ルギー関数を、 $g_{\mathrm{n}}$ 及び $l_{\mathrm{n}}$ は材料に固有なパラメータを示す。本研究 では、 $l_{\mathrm{n}}$ を緩和相当ひずみと呼ぶ。 $N$ は後述する非線形弾塑性ばね の数を表す。また、 $g_{\mathrm{n}}$ は各非線形弾塑性ばねの応力負担係数を表し、 $\sum g_{\mathrm{n}}=1$ となる。 $L$ は Simoの粘弾性構成則における時間に代わって導 入した状態変数であり、(2)式にて定義される。

$$
L=\int_{0}^{t} \sqrt{\frac{2}{3} \mathbf{D}: \mathbf{D}} \mathrm{d} t
$$

ここで、D は変形速度テンソルであり、 $L$ は変形開始時間から現時 刻までの累積相当ひずみに対応する。(2)式にて用いている記号『:』 はスカラー積を表し、下式にて定義される。

$$
\mathbf{A}: \mathbf{B} \equiv \operatorname{Tr}\left(\mathbf{A} \mathbf{B}^{T}\right)
$$

本構成則の力学模型を図 1 に示寸。(1)式の右辺第 1 項が非線形弾 性ばね部分に相当し、同じく右辺第 2 項が非線形弾塑性ばね部分に 相当する。非線形弾塑性ば祁分における摩擦要素の抵抗力が変形 履歴により緩和することが本構成則の大きな特徴の 1 つである。例 えば、時刻 $t \sim t+\Delta t$ の間において応力変化 $\Delta \mathbf{S}_{t \sim t+\Delta t}$ が生じた場合、その 増分応力はその後の変形履歴と共に減少し、変形履歴が緩和相当ひ ずみ $l_{\mathrm{n}}$ まで達すると増分応力は $\Delta \mathbf{S}_{t \sim t+\Delta t} / \mathrm{e}$ まで緩和する。本構成則は、 このような瞬間的な応力変化の重畳で現時刻における応力を表現す る。

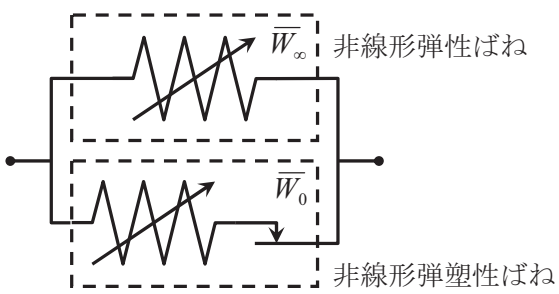

図 1 力学模型

\section{2 弾塑性構成則の水平 2 方向復元カモデルへの縮約}

(1)及び(2)式に示した変形履歴積分型の弾塑性構成則は 6 自由度 変形に対して定義されており、積層ゴムの復元力モデルとして用い るためには水平 2 方向せん断変形成分のみに自由度を縮約する必要 がある。そこで、図 2 に示すように座標軸を定義し、 $x_{1}$ 軸及び $x_{2}$ 軸方向に単純せん断変形する条件のもと、(1)及び(2)式より積層ゴム の復元力モデルを導出する。

ある基準時間 $t_{0}$ における各物質の位置べクトルを $\mathbf{X}$ 、現時刻 $t$ に おける物質点 $\mathbf{X}$ の位置ベクトルを $\mathbf{x}$ とすると、現時刻 $t$ における $x_{1}$ 及び $x_{2}$ 軸方向のせん断ひずみが $\gamma_{1}$ 及び $\gamma_{2}$ の時、 $\mathbf{X}$ と $\mathbf{x}$ の間には下式 が成立する。

$$
\left\{\begin{array}{l}
x_{1}=X_{1}+\gamma_{1} X_{3} \\
x_{2}=X_{2}+\gamma_{2} X_{3} \\
x_{3}=X_{3}
\end{array}\right.
$$

(4)式より、 $\mathrm{d} \mathbf{X}$ から $\mathrm{d} \mathbf{x}$ への線形変換を表現する変形勾配テンソル $\mathbf{F}$ は下式の通りとなる。

$$
\mathbf{F}=\left(\begin{array}{ccc}
1 & 0 & \gamma_{1} \\
0 & 1 & \gamma_{2} \\
0 & 0 & 1
\end{array}\right)
$$

よって、右 Cauchy-Green 変形テンソル $\mathbf{C}$ は下式の通り導かれる。

$$
\mathbf{C}=\mathbf{F}^{T} \mathbf{F}=\left(\begin{array}{ccc}
1 & 0 & \gamma_{1} \\
0 & 1 & \gamma_{2} \\
\gamma_{1} & \gamma_{2} & \gamma_{1}^{2}+\gamma_{2}^{2}+1
\end{array}\right)
$$

また、現時刻における速度場の勾配を示寸速度勾配テンソル $\mathbf{L}$ は下 式の通りとなる。

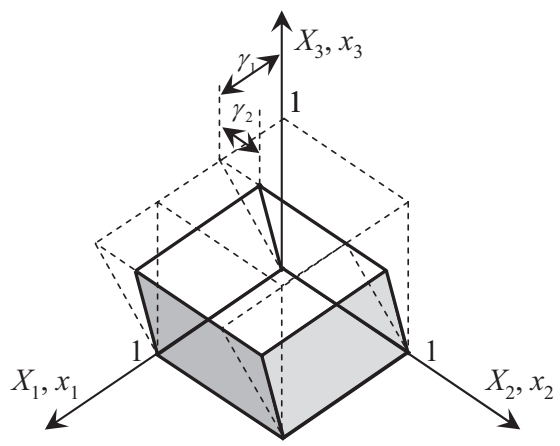

図 2 座標軸の定義 


$$
\mathbf{L}=\dot{\mathbf{F}} \mathbf{F}^{-1}=\left(\begin{array}{ccc}
0 & 0 & \dot{\gamma}_{1} \\
0 & 1 & \dot{\gamma}_{2} \\
0 & 0 & 0
\end{array}\right)
$$

ここで、各変数の上の『・』は時間微分を表し、以降、同様の定義 とする。変形速度テンソル $\mathbf{D}$ は式(7)より下式の通り導かれる。

$$
\mathbf{D}=\frac{1}{2}\left(\mathbf{L}+\mathbf{L}^{T}\right)=\frac{1}{2}\left(\begin{array}{ccc}
0 & 0 & \dot{\gamma}_{1} \\
0 & 0 & \dot{\gamma}_{2} \\
\dot{\gamma}_{1} & \dot{\gamma}_{2} & 0
\end{array}\right)
$$

よって、状態変数 $L$ は、(2)式の定義から以下の通り算出される。

$$
L=\frac{1}{\sqrt{3}} \int_{\chi}|d s|
$$

ここで、 $\chi$ は変形開始時刻 $t_{0}$ から現時刻 $t$ までの変形軌道を示し、(9) 式はその変形軌道に対する線積分を表す。状態変数 $L$ は、変形開始 時刻 $t_{0}$ から現時刻 $t$ までにおける累積せん断ひずみの $1 / \sqrt{3}$ 倍に等し く、これは累積相当せん断ひずみを意味する。

いま、非圧縮を仮定すると、 1 次のひずみの不変量 $I_{1}$ 及び 3 次の ひずみの不変量 $I_{3}$ は下式の通りとなる。

$$
I_{1}=\gamma_{1}^{2}+\gamma_{2}^{2}+3
$$

$I_{3}=1$

真応力テンソル $\boldsymbol{\sigma}$ は第 2Piola-Kirchhoff 応力 $\mathbf{S}$ と変形勾配テンソル $\mathbf{F}$ を用いて(12)式から求められる。

$$
\boldsymbol{\sigma}=\frac{1}{\sqrt{I_{3}}} \mathbf{F S F}^{T}
$$

よって、せん断ひずみ $\gamma_{1}$ 及び $\gamma_{2}$ によるせん断応力 $\tau_{1}$ 及び $\tau_{2}$ は以下の ように表される。

$$
\begin{aligned}
& \tau_{1}\left(\gamma_{1}, \gamma_{2}\right)=\sigma_{13}=S_{13}+\gamma_{1} S_{33} \\
& \tau_{2}\left(\gamma_{1}, \gamma_{2}\right)=\sigma_{23}=S_{23}+\gamma_{2} S_{33}
\end{aligned}
$$

(1)式におけるひずみエネルギー関数は、本研究においては、 $\bar{W}_{\infty}$ については(15)式にて定義される Yeoh モデル ${ }^{21)} の$ 第 2 項までを考慮

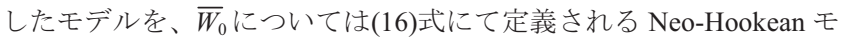
デル 22)を適用した。

$$
\begin{aligned}
& \bar{W}_{\infty}=a\left(\bar{I}_{1}-3\right)+b\left(\bar{I}_{1}-3\right)^{2} \\
& \bar{W}_{0}=c\left(\bar{I}_{1}-3\right)
\end{aligned}
$$

ここで、 $\bar{I}_{1}$ は 1 次のひずみの低減不変量を、 $a 、 b 、 c$ は材料に固有の パラメータを示す。(13)及び(14)式に、(1)、(15)及び(16)式を代入す ることによりせん断応力 $\tau_{1}$ 及び $\tau_{2}$ が下式の通り導かれる。但し、本
研究では、(1)式における非線形弾塑性ばねの数を示す変数 $N$ を 1 と した。

$$
\begin{aligned}
& \tau_{1}\left(\gamma_{1}, \gamma_{2}\right)=\gamma_{1}\left\{a^{*}+b^{*}\left(\gamma_{1}^{2}+\gamma_{2}^{2}\right)\right\}+\frac{c^{*}}{3}\left\{\varsigma_{1}\left(\gamma_{1}, \gamma_{2}\right)-\gamma_{1} \eta\left(\gamma_{1}, \gamma_{2}\right)\right\} \\
& \tau_{2}\left(\gamma_{1}, \gamma_{2}\right)=\gamma_{2}\left\{a^{*}+b^{*}\left(\gamma_{1}^{2}+\gamma_{2}^{2}\right)\right\}+\frac{c^{*}}{3}\left\{\varsigma_{2}\left(\gamma_{1}, \gamma_{2}\right)-\gamma_{2} \eta\left(\gamma_{1}, \gamma_{2}\right)\right\}
\end{aligned}
$$

ここで、式の簡略化のために、 $2 a \rightarrow a^{*} 、 4 b \rightarrow b^{*} 、 2 g c \rightarrow c^{*} 、 \sqrt{3} L \rightarrow \Gamma$ 、 $\sqrt{3} l \rightarrow l^{*}$ と各変数を置き直している。また、 $\zeta_{1} 、 \zeta_{2}$ 及び $\eta$ は下式にて 定義される軌道 $\chi$ における線積分を示している。

$$
\begin{aligned}
& \varsigma_{1}\left(\gamma_{1}, \gamma_{2}\right)=\int_{\chi} \frac{d}{d \Gamma^{\prime}}\left[\gamma_{1}^{\prime}\left(\gamma_{1}^{\prime 2}+\gamma_{2}^{\prime 2}+3\right)\right] e^{-\frac{\Gamma-\Gamma^{\prime}}{l^{*}}} d \Gamma^{\prime} \\
& \left.\varsigma_{2}\left(\gamma_{1}, \gamma_{2}\right)=\int_{\chi} \frac{d}{d \Gamma^{\prime}}\left[\gamma_{2}^{\prime}\left(\gamma_{1}^{\prime 2}+\gamma_{2}^{\prime 2}+3\right)\right]\right]^{-\frac{\Gamma-\Gamma^{\prime}}{l^{*}}} d \Gamma^{\prime} \\
& \eta\left(\gamma_{1}, \gamma_{2}\right)=\int_{\chi} \frac{d}{d \Gamma^{\prime}}\left[\left(\gamma_{1}^{\prime 2}+\gamma_{2}^{\prime 2}\right)\right] e^{-\frac{\Gamma-\Gamma^{\prime}}{l^{\circ}}} d \Gamma^{\prime}
\end{aligned}
$$

以上により、変形履歴積分型の水平 2 方向変形に対応した復元力モ デルが導出される。

数值計算を行うためには、(17) (21)式を時間的に離散化する必要 がある。いま、時刻 $t_{\mathrm{n}}$ における $x_{1}$ 及び $x_{2}$ 軸方向のせん断ひずみを $\gamma_{1, \mathrm{n}}$

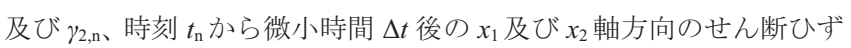
みの増分を $\Delta \gamma_{1, \mathrm{n}}$ 及び $\Delta \gamma_{2, \mathrm{n}}$ とし、2 次の微小項を無視すると、時刻 $t_{\mathrm{n}+1}\left(=t_{\mathrm{n}}+\Delta t_{\mathrm{n}}\right)$ における $x_{1}$ 及び $x_{2}$ 軸方向のせん断応力 $\tau_{1, \mathrm{n}+1}$ 及び $\tau_{2, \mathrm{n}+1}$ は 下式の通り導かれる。

$$
\begin{aligned}
\tau_{1, n+1}= & \tau_{1, n}+\left\{a^{*}+b^{*}\left(3 \gamma_{1, n}^{2}+\gamma_{2, n}^{2}\right)\right\} \Delta \gamma_{1, n}+2 b^{*} \gamma_{1, n} \gamma_{2, n} \Delta \gamma_{2, n} \\
& +\frac{c^{*}}{3}\left\{\frac{\Delta \Gamma_{n}}{l^{*}}\left(-\varsigma_{1, n}+\gamma_{1, n} \eta_{n}\right)-\eta_{n} \Delta \gamma_{1, n}+\left(\gamma_{1, n}^{2}+\gamma_{2, n}^{2}+3\right) \Delta \gamma_{1, n}\right\} \\
\tau_{2, n+1}= & \tau_{2, n}+\left\{a^{*}+b^{*}\left(\gamma_{1, n}^{2}+3 \gamma_{2, n}^{2}\right)\right\} \Delta \gamma_{2, n}+2 b^{*} \gamma_{1, n} \gamma_{2, n} \Delta \gamma_{1, n} \\
& +\frac{c^{*}}{3}\left\{\frac{\Delta \Gamma_{n}}{l^{*}}\left(-\varsigma_{2, n}+\gamma_{2, n} \eta_{n}\right)-\eta_{n} \Delta \gamma_{2, n}+\left(\gamma_{1, n}^{2}+\gamma_{2, n}^{2}+3\right) \Delta \gamma_{2, n}\right\} \\
\varsigma_{1, n+1}= & \left(1-\frac{\Delta \Gamma_{n}}{l^{*}}\right) S_{1, n}+\left(3 \gamma_{1, n}^{2}+\gamma_{2, n}^{2}+3\right) \Delta \gamma_{1, n}+2 \gamma_{1, n} \gamma_{2, n} \Delta \gamma_{2, n} \\
\varsigma_{2, n+1}= & \left(1-\frac{\Delta \Gamma_{n}}{l^{*}}\right) \varsigma_{2, n}+2 \gamma_{1, n} \gamma_{2, n} \Delta \gamma_{1, n}+\left(\gamma_{1, n}^{2}+3 \gamma_{2, n}^{2}+3\right) \Delta \gamma_{2, n} \\
\eta_{n+1}= & \left(1-\frac{\Delta \Gamma_{n}}{l^{*}}\right) \eta_{n}+2 \gamma_{1, n} \Delta \gamma_{1, n}+2 \gamma_{2, n} \Delta \gamma_{2, n}
\end{aligned}
$$

ここで、 $\zeta_{1, \mathrm{n}} 、 \zeta_{2, \mathrm{n}}$ 及び $\eta_{\mathrm{n}}$ は、変形開始時刻から時刻 $t_{\mathrm{n}}$ までにおける 変形軌跡 $\chi$ に沿った(19) (21)式の線積分の結果を示す。ある初期条 件を与え、(22) (26)式を逐次計算することで、水平 2 方向の強制せ ん断ひずみ増分に対するせん断応力増分を求めることができる。当 然ながら、図 2 の $X_{2}$ 方向のせん断ひずみをゼロ、即ち $\gamma_{2}=0$ とすれ ば、(22) (26)式は水平 1 方向復元力モデルとなる。上式からも明ら かなように、本提案モデルは、弾塑性モデルでありながら降伏判定 
などの条件分岐を必要とせず、逐次計算のみで解析計算ができるこ とが特徴の 1 つである。

\section{3. 水平 2 方向変形実験}

本章では、2 章にて提案した復元力モデルの妥当性を確認するた めに実施した高減衰積層ゴムの水平 2 方向変形実験 ${ }^{23}$ について述べ る。

\section{1 実験概要}

試験体形状とその諸元を図 3 及び表 1 に示す。積層ゴムの有効径 は $158 \mathrm{~mm} 、$ ゴム一層厚さは $1.26 \mathrm{~mm}$ 、内部鋼板厚さは $0.8 \mathrm{~mm}$ であり、 1 次形状係数 $S_{1}$ は $31.3 、 2$ 次形状係数 $S_{2}$ は 5.02 と 4.05 の 2 種類とし た。高減衰ゴムは荷重履歴依存性の小さい種類のものを用いた ${ }^{24)}$ 。 使用した高減衰ゴムの $\gamma=1.0$ 時のせん断弾性係数 $G_{\mathrm{eq}}$ は $0.620 \mathrm{MPa} 、$ 等価減衰定数 $H_{\mathrm{eq}}$ は 0.240 である。

試験条件を表 2 に示寸。試験ひずみは、1 方向変形試験 1 パター ンと 2 方向変形試験 2 パターンの計 3 パターンとした。 2 方向変形 試験は、長軸 $(X)$ : 短軸 $(Y)=2: 1$ とする棈円変形試験と、同じく長 軸 $(\mathrm{X})$ : 短軸 $(\mathrm{Y})=2: 1$ とする 8 の字変形試験の 2 パターンである。 2 方向変形試験における試験ひずみの変形オービットを図 4 に示す。 図中の○囲み数字は変形順序を示す。1 方向変形試験、2 方向変形試 験共に各試験ひずみは連続的に加力した。各試験ひずみにおける加 カサイクル数は長軸方向の変形に対して 3 サイクルとした。楕円変 形試験の加力振動数は長軸方向において $0.1 \mathrm{~Hz} 、 8$ の字変形試験の加 力振動数は長軸方向において $0.01 \mathrm{~Hz}$ とした。この時、短軸方向にお ける加力振動数は、それぞれ、 $0.1 \mathrm{~Hz}$ と $0.02 \mathrm{~Hz}$ とになる。試験体 $\mathrm{A}$ の試験面圧は $13 \mathrm{MPa}$ 、試験体 B の試験面圧は $10.7 \mathrm{MPa}$ とし、水平加 カ中は一定とした。
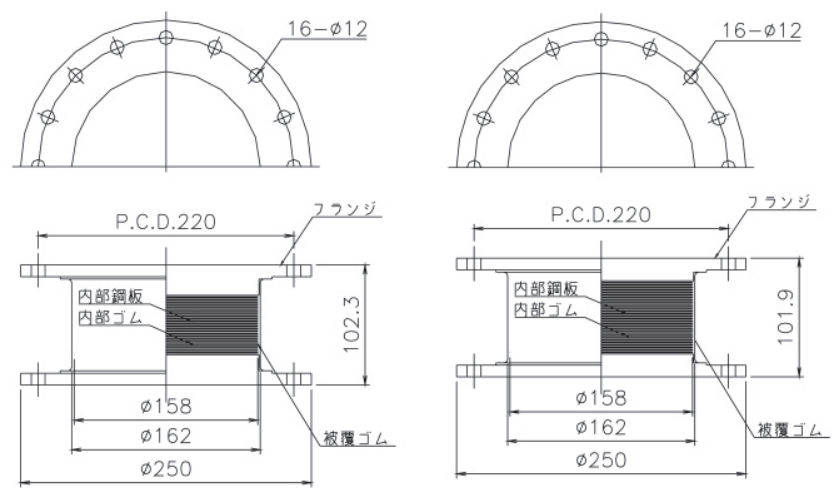

(a) 試験体 A

(b) 試験体 B
試験時の様子を図 5 に示す。試験体は、長軸及び短軸方向に配置 されたリニアガイドが取り付けられた試験台上に設置され、水平変 形はロードセルを介して取り付けられた 2 本のアクチュエータにて 与えられる。積層ゴムの水平変形量は、試験台の変位量をレーザー 変位計で測定することで求めた。また、試験体の変形状態を確認す るために、長軸方向にビデオカメラを設置した。

\section{2 実験結果}

実験により得られた荷重変形関係を図 6 に示す。楕円変形試験の 長軸方向の結果について、1 方向変形試験の結果と比較してせん断 ひずみがゼロ付近においてせん断応力の増加が見られる。楕円変形 試験においては、長軸方向のせん断ひずみがゼロの時に短軸方向の せん断ひずみが最大となるため、このせん断応力の増加は短軸方向 の変形による影響であると推測される。長軸方向のせん断ひずみが

表 1 試験体諸元

\begin{tabular}{ccccc}
\hline 試験体 & $S_{1}$ & $S_{2}$ & ゴム部外径 & ゴム部構成 \\
\hline \hline $\mathrm{A}$ & 31.3 & 5.02 & $\phi 158$ & $1.26 \mathrm{~mm} \times 25$ 層 $=31.5 \mathrm{~mm}$ \\
\hline $\mathrm{B}$ & 31.3 & 4.05 & $\phi 158$ & $1.26 \mathrm{~mm} \times 31$ 層=39.1 $\mathrm{mm}$ \\
\hline
\end{tabular}

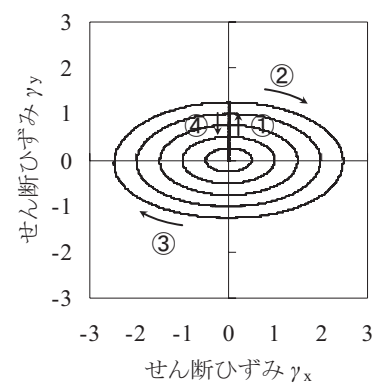

(a) 楕円

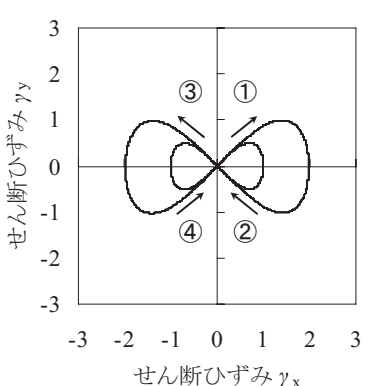

(b) 8 の字
図 4 変形オービット

注) 図中の○囲み数字は変形順序を示す。

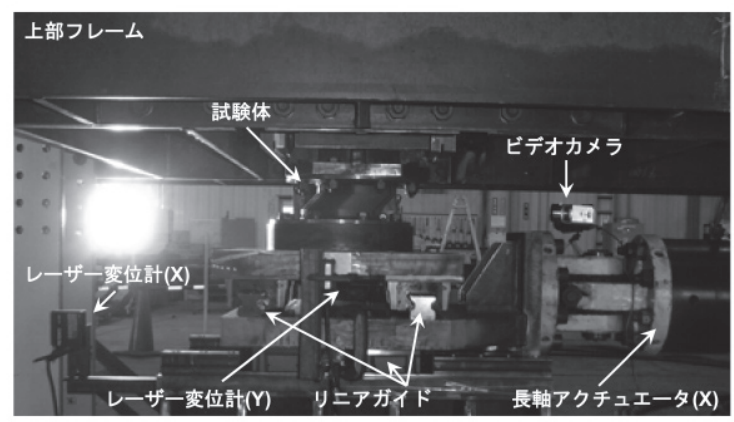

図 5 試験時の様子

表 2 試験条件

\begin{tabular}{|c|c|c|c|c|}
\hline & 試験体 & 試験ひずみ $\left(\gamma_{\mathrm{x}}, \gamma_{\mathrm{y}}\right)$ & 面圧 $\sigma(\mathrm{MPa})$ & 周波数 $\left(f_{\mathrm{x}}, f_{\mathrm{y}}\right)(\mathrm{Hz})$ \\
\hline 1 方向 & A & $( \pm 0.5,0) \rightarrow( \pm 1.0,0) \rightarrow( \pm 1.5,0) \rightarrow( \pm 2.0,0) \rightarrow( \pm 2.5,0)$ & 13.0 & $(0.1,-)$ \\
\hline 2 方向(楕円) & A & $( \pm 0.5, \pm 0.25) \rightarrow( \pm 1.0, \pm 0.5) \rightarrow( \pm 1.5, \pm 0.75) \rightarrow( \pm 2.0, \pm 1.0) \rightarrow( \pm 2.5, \pm 1.25)$ & 13.0 & $(0.1,0.1)$ \\
\hline 2 方向(8 の字) & B & $( \pm 1.0, \pm 0.5) \rightarrow( \pm 2.0, \pm 1.0)$ & 10.7 & $(0.01,0.02)$ \\
\hline
\end{tabular}


ゼロの時に短軸方向のせん断ひずみもゼロとなる 8 の字変形試験に おいては、長軸方向の荷重変形関係において、楕円変形試験に見ら れたせん断ひずみがゼロ付近におけるせん断応力の増加は見られな い。8 の字変形試験において、短軸方向のせん断ひずみが最大とな るのは、例えば長軸方向の最大せん断ひずみが 2.0 の実験の場合は、 最大せん断ひずみ経験後の除荷過程でせん断ひずみが 1.4 程度とな る時であり、その付近では、長軸方向の荷重変形関係において、楕 円変形試験之同様に荷重履歴曲線に膨らみが見られる。

短軸方向の荷重変形関係については、楕円変形試験も 8 の字変形 試験も長軸方向の変形の影響を受けて特異な振る舞いを示す。楕円 変形試験においては、せん断ひずみがゼロ付近で最大応力を示し、8 の字変形試験においては、荷重履歴曲線の下半分が大きく膨らむ結 果となっている。これらの荷重変位関係が特異となる䇢所は、どち らも長軸方向のせん断ひずみが大きな箇所であり、主軸である長軸 方向の変形による影響を短軸方向の荷重変形関係は大きく受けてい ると考えられる。このことは、水平 2 方向変形における荷重変位関 係を復元力モデルで精度よく再現するためには、求めるせん断応力 と同じ方向のせん断ひずみのみならず、その直交方向のせん断ひず みによる影響を考慮する必要があることを示している。

\section{4. 提案モデルによる実験結果の再現と既往のモデルとの比較}

本章では、提案モデルを用いた解析を実施し、3 章にて示した実
験結果の再現性について検討する。本研究における提案モデルは、 有限要素法に用いられる変形履歴積分型の弾塑性構成則を水平 2 方 向せん断変形成分に自由度を縮約することで積層ゴムの水平方向の 復元力特性のみを表現することとした復元力モデルである。従って、 積層ゴムの上下フランジ間の相対変位を提案モデルに入力すること で、その水平復元力特性を算出できる。また、提案モデルは有限要 素法の構成則と基本式が同一なため、同じ材料パラメータを用いて 有限要素解析を実施し、積層ゴムの力学的挙動を詳細に検討するこ とが可能である。そこで、提案モデルと同じ材料パラメータを用い た有限要素解析を実施し、その結果について、提案モデルの解析結 果との比較検討を行う。また、既往の復元力モデルとの比較として、 現在広く利用されている MSS モデルを用いた解析を実施し、その結 果についても比較検討を行う。

\section{1 提案モデルによる解析概要}

提案モデルによる解析は、(22) (26)式に表 2 に示した試験ひずみ を入力することで実施した。初期条件は、ひずみ、応力ともにゼロ である。事前検討により決定した提案モデルに用いた材料パラメー タを表 3 に示寸。
表 3 材料パラメータ

\begin{tabular}{cccc}
\hline$a^{*}(\mathrm{MPa})$ & $b^{*}(\mathrm{MPa})$ & $c^{*}(\mathrm{MPa})$ & $l^{*}$ \\
\hline \hline 0.3203 & 0.01533 & 0.8237 & 0.3295 \\
\hline
\end{tabular}

(a) 1 方向変形試験

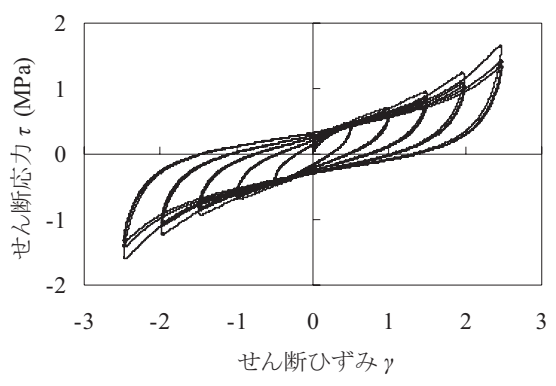

(b) 楕円変形試験
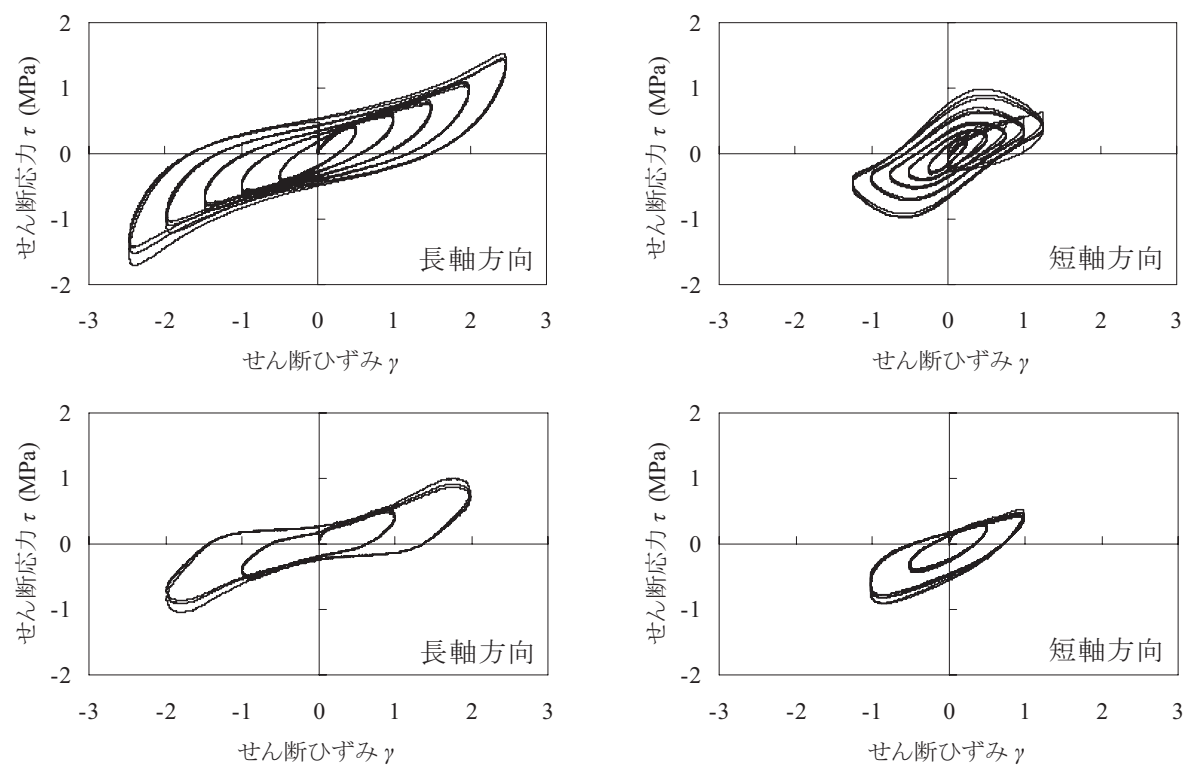

図 6 荷重変形関係

注) 左列図:長軸方向、右列図:短軸方向の実験結果を示す。 


\section{2 有限要素解析概要}

本研究に用いた有限要素モデルの一例として、試験体 $\mathrm{A}$ の有限要 素モデルを図 7 に示す。有限要素モデルの形状は、図 3 に示した実 験評価に用いた試験体と同じである。但し、被覆ゴム及び取付フラ ンジ部分については、解析結果に大きく影響しないためモデル化を 省略している。また、前章にて示した実験評価における試験条件の 範囲においては、積層ゴムの鉛直方向の要素分割数が解析結果に及 ぼす影響は小さいため、内部ゴム及び内部鋼板について鉛直方向へ の要素分割は行っていない。内部ゴムには 3 次元アイソパラメトリ ック要素に圧力変数を自由度とする節点を 1 つ追加した 6 面体 9 節 点要素を、内部鋼板には 6 面体 8 節点の一様次数低減積分要素を用 いた。

内部ゴムの等容変形に対する構成則は、(1)及び(2)式にて示した変 形履歴積分型の弾塑性構成則を用いた。材料パラメータは提案モデ ルの材料パラメータと同じ表 3 の通りとした。体積変形に対する構 成側は、以下のひずみエネルギー関数 $W_{\mathrm{vol}}$ を用いた ${ }^{25)}$

$$
W_{\mathrm{vol}}=\frac{9}{2} \kappa\left(J^{1 / 3}-1\right)^{2}
$$

ここで、Jは変形勾配テンソル F $の$ Jacobian であり、体積変化率を 示す。火は体積弾性率を表すパラメータであり、本研究では $1500 \mathrm{MPa}$ とした。内部鋼板については完全弾性体を仮定し、ヤング率を $205 \mathrm{GPa}$ 、ポワソン比を 0.3 とした。

解析条件は、表 2 に示した実験評価における試験条件と同様とし た。有限要素解析には MSC.Marc を用いた。内部ゴムの等容変形に 対する構成則については、MSC.Marc に実装されているユーザーサ ブルーチン機能を利用した。

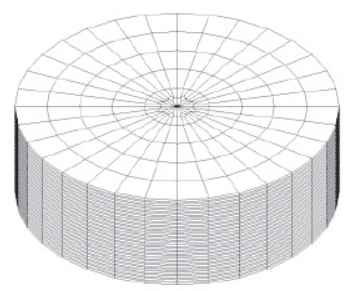

図 7 有限要素モデル(試験体 $\mathrm{A})$

\subsection{MSS モデル概要}

MSS モデルの力学模型を図 8 に示す。MSS モデルは、同じ復元 力特性を持ったせん断ばねを等角度に配置することで、水平 2 方向 の復元力特性を表現するモデルである。本検討では、せん断ばねの 数は 8 とした。また、せん断ばねに与える復元力特性として、修正 バイリニアモデルを用いた。修正バイリニアモデルにおける 3 つ パラメータ $\left(1\right.$ 次剛性 $K_{1} 、 2$ 次剛性 $K_{2}$ 、切片荷重 $\left.Q_{\mathrm{d}}\right)$ は、実験から得 られた復元力特性における吸収エネルギーと復元力モデルによる吸 収エネルギーが等価となる条件下のもと、下式にて決定した

$$
K_{1}=\frac{2 u-\pi H_{\mathrm{eq}}+u \pi H_{\mathrm{eq}}}{2 u-\pi H_{\mathrm{eq}}} K_{\mathrm{eq}}
$$

$$
\begin{aligned}
& K_{2}=(1-u) K_{\mathrm{eq}} \\
& Q_{d}=u \cdot K_{\mathrm{eq}} \cdot \delta_{\mathrm{ex}}
\end{aligned}
$$

ここで、 $u$ は最大経験変位における荷重と切片荷重の比を示寸降伏 荷重特性係数を、 $K_{\mathrm{eq}}$ は等価剛性を、 $H_{\mathrm{eq}}$ は等価減衰定数を示す。等 価剛性 $K_{\mathrm{eq}}$ 、等価減衰定数 $H_{\mathrm{eq}}$ 、降伏荷重特性係数 $u$ は、図 6 (a) に示 した 1 方向変形試験の結果からせん断ひずみ $\gamma$ の関数として定義し た。定義した各水平復元力特性のひずみ依存式を表 4 に示す。 $K_{\mathrm{eq}}$ は $K_{\mathrm{eq}}$ に積層ゴムのゴム総厚さを乗じ、有効面積で除したせん断弾 性係数 $G_{\mathrm{eq}}$ で示している。

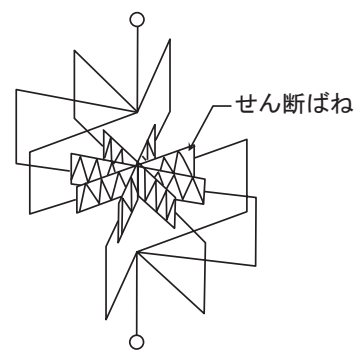

図 8 MSS モデルの力学模型

表 4 水平復元力特性のひずみ依存性

\begin{aligned} &$G_{\text {eq }}(\gamma)= \begin{cases}0.8801 & (\gamma<0.5) \\ 5.083 \times 10^{-1} \gamma^{2}-1.254 \gamma+1.380 & (0.5 \leq \gamma \leq 1.0) \\ -2.488 \times 10^{-2} \gamma^{3}+2.287 \times 10^{-1} \gamma^{2}-6.181 \times 10^{-1} \gamma+1.049 & (1.0<\gamma)\end{cases} \\ &$\hline \hline$H_{\text {eq }}(\gamma)= \begin{cases}0.1887 & (\gamma<0.5) \\ -1.098 \times 10^{-2} \gamma^{2}+1.177 \times 10^{-2} \gamma+1.856 \times 10^{-1} & (0.5 \leq \gamma)\end{cases} \\ &$\hline \hline$(\gamma)= \begin{cases}0.3739 & (\gamma<0.5) \\ -1.537 \times 10^{-2} \gamma^{2}-1.537 \times 10^{-2} \gamma+3.854 \times 10^{-1} & (0.5 \leq \gamma)\end{cases} \\ &$\hline\end{aligned}

\section{4 解析結果の比較}

提案モデル、有限要素モデル、MSS モデルによる解析結果の比較 を図 9 図 11 に示寸。提案モデルによる解析結果は、全ての試験結 果において、実験結果と高い精度で一致していることが確認できる。 これらの比較により、本提案モデルは妥当であると判断できる。

有限要素モデルによる解析結果と提案モデルによる解析結果は、 ほぼ完全に一致している。このことは、積層ゴムの復元力特性は水 平せん断変形に対する応答が支配的であり、水平せん断変形のみに 自由度を縮約した提案モデルでも十分に高い精度が確保できている ことを示している。

MSS モデルの水平 1 方向変形解析結果については、せん断ひずみ が 2.0 までの範囲においては、ある程度実験結果を再現しているが、 せん断ひずみが 2.5 の解析結果については、除荷過程における荷重 履歴曲線が実験結果と乘離するなど再現性の低下がやや目立つ。水 平 2 方向変形解析結果については、長軸方向のせん断ひずみが 1.0 までの範囲においては実験結果をある程度再現しているが、せん断 ひずみが大きくなるとともに水平 1 方向変形で実験結果をある程度

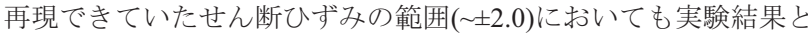




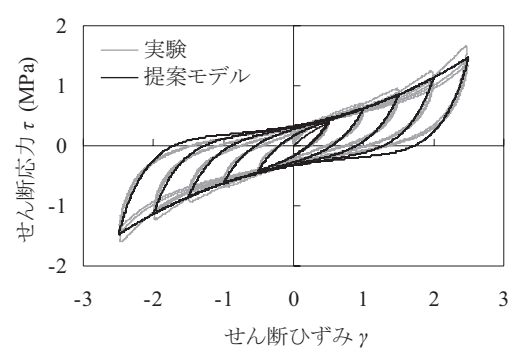

(a) 提案モデル

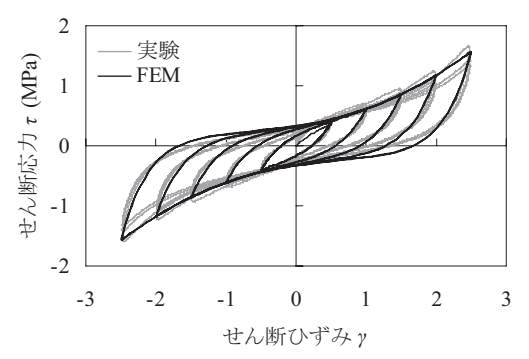

(b) 有限要素モデル

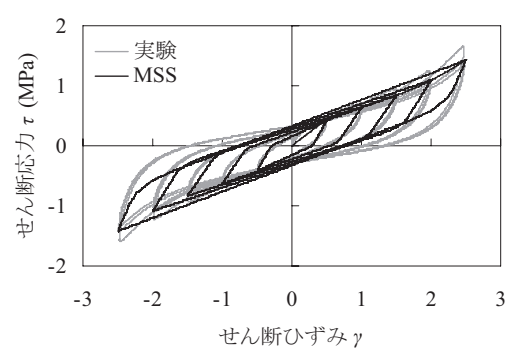

(c) MSS モデル

図91 方向変形試験における各モデルの解析結果の比較
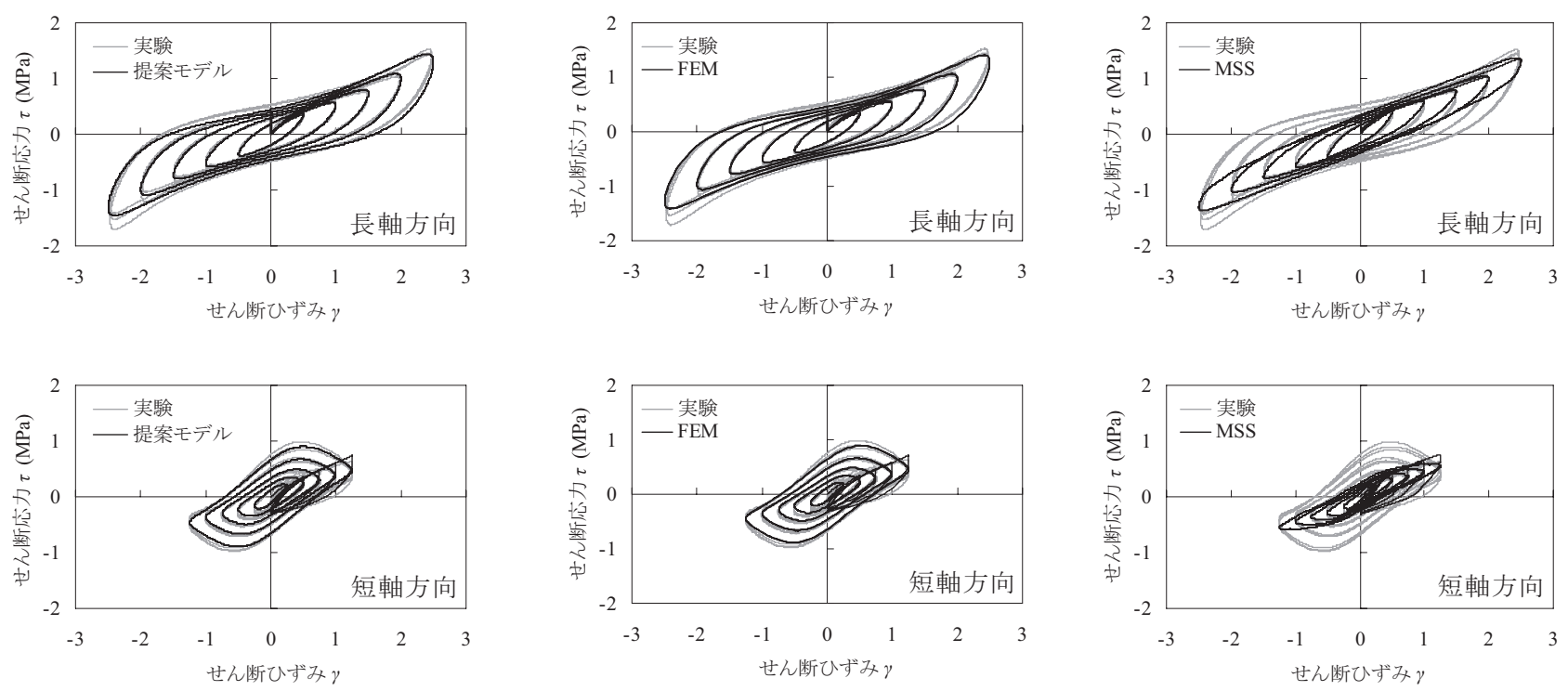

(a) 提案モデル

(b) 有限要素モデル

(c) MSS モデル

図 10 楕円変形試験における各モデルの解析結果の比較
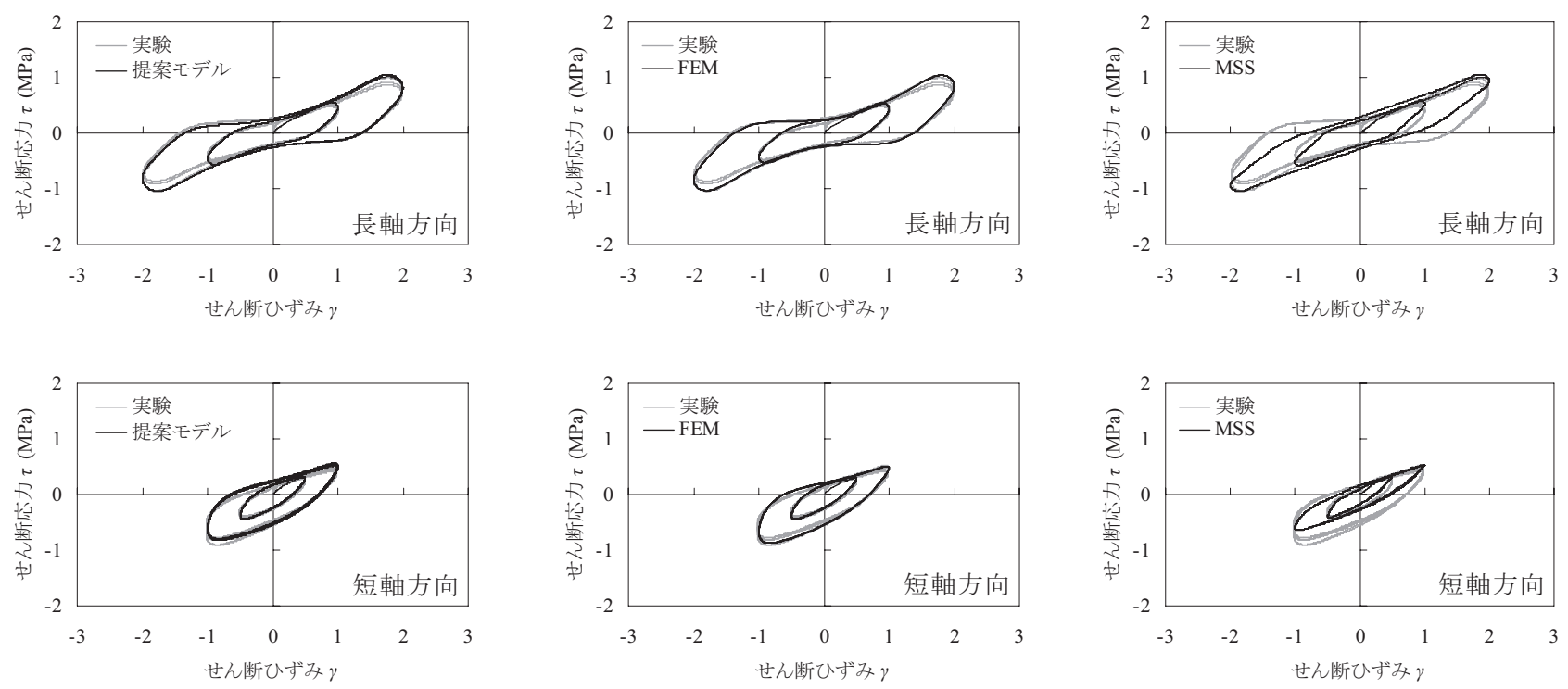

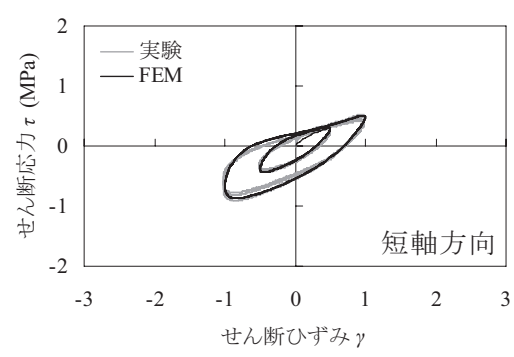

(b) 有限要素モデル

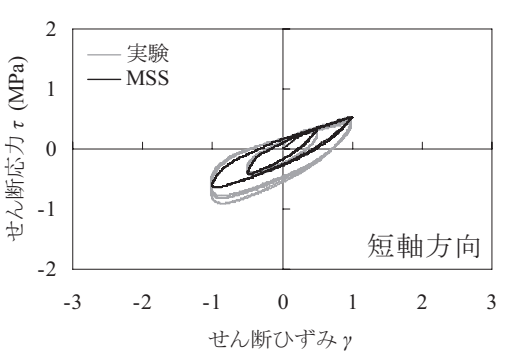

(c) MSS モデル

図 118 の字変形試験における各モデルの解析結果の比較 
の乘離が大きくなる。長軸方向の復元力特性については、楕円変形 試験でも 8 の字変形試験でも、最大応力についてはよく再現してい るが、3 章にて示した荷重履歴曲線の膨らみについては再現性が低 い。また、短軸方向の復元力特性についても、3 章にて示した荷重 変形関係の特異な振る舞いを再現できていない。これらの再現性の 低下は、MSS モデルが水平 2 方向変形によるせん断応力への影響を 十分に表現できず、せん断ひずみの増加と共にその影響が大きくな ることに起因すると推測される。このことは、積層ゴムのせん断ひ ずみが 1.0 を大きく超えるようなひず夕領域で地震時における免震 建物の応答性状を精緻に予測するためには、本提案モデルのような 水平 2 方向変形によるせん断応力への影響を考慮した復元力モデル を積層ゴムに適用する必要性があることを示唆している。

\section{5. まとめ}

本研究では、著者らが提案している変形履歴積分型の弾塑性構成 則を基本式とした高減衰積層ゴムの復元力モデルの提案を行った。 提案した復元力モデルについて、高減衰積層ゴムの水平 2 方向変形 実験の結果と比較し、その妥当性について検討した。その結果、提 案モデルは、高減衰積層ゴムの復元力特性を高い精度で再現できる ことを確認した。また、本研究にて提案した復元力モデルを用いた 解析結果と、提案モデルと同じ材料パラメータを用いた有限要素モ デルによる解析結果を比較し、高い精度で一致することを確認した。 このことは、積層ゴムの復元力特性は水平せん断変形による応答が 支配的であり、水平せん断変形のみに自由度を縮約した提案モデル でも、十分に精度が確保できることを示している。また、提案モデ ルと MSS モデルの解析結果を比較し、MSS モデルの解析結果は提 案モデルの解析結果と比較して実験結果の再現性が低いことを確認 した。これは、MSS モデルが水平 2 方向変形によるせん断応力への 影響を十分に表現できないためであると考えられる。但し、本研究 におけるこれらの検討は、実験の制約により、せん断ひずみ $\gamma$ が 2.5 以下の範囲におけるものである。高減衰積層ゴムの材料非線形性は、 せん断ひずみが大きくなると共に大きくなることが知られており、 より広いひずタ領域における妥当性の確認が今後の課題である。

\section{謝辞}

本研究における実験評価は社団法人日本免震構造協会の『水平 2 方向加力時の免震部材の特性と検証方法』WG(主查:高山峯夫氏)の 下に設置された『高減衰ゴム系積層ゴム支承』SWG(主査: 北村春幸 氏)の成果の一部です。実験評価を進めるにあたり多くのご指導を頂 きました。ここに記して感謝の意を表します。

\section{参考文献}

1）梁堀美英, 関瓦, 佐藤玲司, 笠原泰宏, 芳沢利和：免震用積層ゴムの大 変形 FEM 解析( その $1 \sim 4)$, 日本建築学会大会学術講演梗概集 B, pp.581-590, 1991.9

2）高山峯夫, 多田英之, 百田龍児, 西村保: Isolator の有限要素解析, 日本 建築学会大会学術講演梗概集 B, pp.373-374, 1988.10

3）高山峯夫, 多田英之, 西村保 : Isolator の有限要素解析(その 2 4), 日本 建築学会大会学術講演梗概集 B, pp.663-668, 1990.10

4) 高山峯夫, 多田英之, 吉田献一, 和田章 : Isolator の有限要素解析(その) 5), 日本建築学会大会学術講演梗概集 B, pp.589-590, 1991.9

5）松田泰治, 矢花修一, 塩尻弘雄 : 有限要素法による免震用積層ゴムの大
ひずみ解析法の開発, 電力中央研究所報告, No.U92061, 1993.3

6）高山峯夫，森田慶子：免震構造用積層ゴムの座屈性能に関する有限要素 解析 ーゴム材料の応力-ひずみ関係と中間鋼板厚が与える影響一, 日本 建築学会九州支部研究報告，第 44 号, pp.553-556, 2005.3

7）松田昭博：超弾性体の大変形有限要素解析による積層ゴム免震要素の力 学特性評価に関する研究, 博士論文, 筑波大学システム情報工学研究科, 2002

8）松田昭博：非線形粘弾性モデルを用いた高減衰積層ゴムの有限要素解析, 日本機会学会論文集(A 編)， 68 巻，669 号，pp.709-716，2002.5

9）加藤秀章，森隆浩，室田伸夫，鈴木重信，嶺脇重雄，山本雅史，米田春 美, 東野雅彦: 免震用積層ゴムの水平 2 方向加力時の限界特性に関する 研究, 日本建築学会技術報告集, 第 16 巻, 第 32 号, pp.167-172, 2010.2

10）吉田純司，阿部雅人，藤野陽三 : 高減衰ゴム材料の構成則，土木学会論 文集，No.710/I-60，pp.209-224，2002.7

11）森隆浩, 加藤秀章, 室田伸夫 : 変形履歴積分型の弾塑性構成則を用いた 高減衰積層ゴムの FEM 解析，日本建築学会構造系論文集，第 75 巻，第 658 号, pp.2171-2178, 2010.12

12）藤田隆史, 鈴木重信, 藤田聡 : 建物免震用の高減衰積層ゴムに関する研 究, 日本機械学会論文集(C 編), 56 巻, 523 号, 1990.3

13) M. Kikuchi, I. D. Aiken : An analytical hysteresis model for elastomeric seismic isolation bearings, Earthquake Engineering and Structurl Dynamics. Vol.26, pp.215-231, 1997

14）山本雅史，嶺脇重雄，米田春美，東野雅彦，和田章：高減衰積層ゴム支 承の水平 2 方向変形時の力学特性に関する実大実験およびモデル化, 日 本建築学会構造系論文集, 第 74 巻, 第 638 号, pp.639-645, 2009.4

15）和田章，木下雅彦：MSS モデルを用いた柱降伏型の建物の立体振動解析 (その 1 2), 日本建築学会大会学術講演梗概集 B, pp.313-316, 1985.10

16）嶺脇重雄, 山本雅史, 東野雅彦, 和田章 : 実大性能試験結果の回帰によ る免震用高減衰積層ゴムの特性表現式, 日本建築学会構造系論文集, 第 75 巻，第 652 号，pp.1099-1104， 2010.6

17) M. Abe, J. Yoshida, Y. Fujino : Multiaxial behaviors of laminated rubber bearings and their modeling. I : Experimental study, Journal of Structural Engineering, Vol.130, No.8, pp.1119-1132. 2004.8

18) M. Abe, J. Yoshida, Y. Fujino : Multiaxial behaviors of laminated rubber bearings and their modeling. II : Modeling, Journal of Structural Engineering, Vol.130, No.8, pp.1133-1144. 2004.8

19）菊地優，石井建，山本雅史，米田春美，嶺脇重雄，加藤秀章：高減衰積 層ゴムを用いた免震建物の水平 2 方向応答特性に関する検討(その 1 3), 日本建築学会大会学術講演梗概集 B, pp.249-254, 2010.9

20） J. C. Simo and T. J. R. Hughes : Computational inelasticity, Springer, 1997

21) O. H. Yeoh : Some forms of the strain energy function for rubber, Rubber Chemistry and technology, Volume 66, Issue 5, 754-771, 1993.11

22) R. W. Ogden : Nonlinear Elastic Deformations, Dover, 1998

23）加藤秀章, 室田伸夫，山本雅史，下沖航，北村春幸 : 水平 2 方向加力実 験における高減衰積層ゴムの力学特性に関寸る研究(その 1 2), 日本建築 学会大会学術講演梗概集 B, pp.261-264, 2010.9

24）室田伸夫，西村圭司，菊地隆志，奥津宣幸，鍬本賢二，鈴木重信：荷重 履歴依存性を改良した新高減衰積層ゴムの開発(その 1 2), 日本建築学会 大会学術講演梗概集 B, pp.879-882, 2007.8

25）MSC SOFTWARE : MSC.MARC ユーザーズマニュアル A 編， 2003. 